\title{
Response of Nitrogen Rates and Irrigation Methods on Nutrients Uptake, Nitrogen and Water Use Efficiency on Potato
}

\author{
Devashri Maan, A.K. Bhatia, Vikram* and Anshul Duhan \\ Department of Vegetable Science, College of Agriculture, CCS Haryana Agricultural \\ University, Hisar-125004, Haryana, India \\ *Corresponding author
}

\section{A B S T R A C T}

\section{Keywords}

Economics,

Fertigation,

Irrigation methods,

Potato, Yield

\section{Article Info}

Accepted:

15 October 2018

Available Online:

10 November 2018
In this study, the effects of different irrigation methods on nutrients uptake, nitrogen and water use efficiency on potato were investigated. The experiment was conducted at Research Farm of the Department of Vegetable Science and in Laboratory of the Department of Soil Science, CCS Haryana Agricultural University, Hisar during Rabi season of 2015-16 and 2016-17. To find the effect of irrigation methods and nitrogen levels on nutrients and water use efficiency of different treatments. The potato variety used for the investigation was Kufri Bahar. The treatments comprising of drip and furrow irrigation methods and five recommended dose of nitrogen $(60,80,100,120$ and $140 \%$ of RDN) were laid out in split plot design with three replications. The irrigation methods showed significant differences in all the treatments in both the years. The maximum value for nutrient use efficiency $(\mathrm{kg} / \mathrm{ha} / \mathrm{kg})$, water use efficiency $(\mathrm{kg} / \mathrm{ha} / \mathrm{cm})$, dry matter content in tubers and foliage $(\%)$, and nutrient uptake by tubers and foliage $(\mathrm{kg} / \mathrm{ha})$ were recorded with $100 \%$ of RDN and drip irrigation. Hence, $100 \%$ of RDN with drip irrigation condition have shown the best treatment combination for potato production under semiarid conditions of Hisar, Haryana.

\section{Introduction}

In India, potato was first introduced by the Portuguese traders in $17^{\text {th }}$ century and its cultivation was further extended to North India by the Britishers (Nath et al., 2008, Pandey and Sarkar, 2005). Presently, India is the second largest producer of potato in the world after China and the crop occupies 21.17 lakh hectares with a production of 434.17 lakh million tonnes and productivity 21.00 t/ha during 2015-16(Anonymous; 2016). Potato is a temperate region crop but there is great variation in the gene pool with respect to crop response to thermoperiods. Generally, potato crop is raised in India when maximum temperature is below $35^{\circ} \mathrm{C}$ and the minimum temperature is below $20^{\circ} \mathrm{C}$ with ideal tuberization temperature between $16-22^{\circ} \mathrm{C}$. Potato can be grown on alluvial, black, red and laterite soils having $\mathrm{pH}$ in the range of 5.5-8.0 (Pandey, 2007). Among various factors playing important role in deciding the production, productivity and keeping quality of the potato, the irrigation and fertilization are most dominant ones. The water either 
supply in both excess or in deficit declines potato yield. Improper irrigation management practices not only waste the expensive and scare water resources but also reduce the tuber yield and quality.

Sound water management has the potential to improve nutrient use efficiency. The introduction of well-tested, efficient fertilizer application through irrigation water or "fertigation" techniques could help turn vast areas of arid and semi-arid land in many parts of the world into farmland, as well as preventing water from being wasted in conventional irrigation systems. Drip irrigation has the greatest potential for the efficient use of water and ferlilizers. The limited area of wetting under trickle irrigation reduces the active root zone and also the foraging area of plants to draw water and nutrients from the soil. For minimizing the cost of irrigation and fertilizers, adoption of drip irrigation with fertigation is essential which will maximize the nutrient uptake, while using minimum amount of water and fertilizer, minimum loss of $\mathrm{N}$ due to leaching, supplying nutrients directly to root zone in available forms, control of nutrient concentration in soil solution and saving in application cost. Thus, fertigation becomes prerogative for increasing the yield of most of the crops under drip irrigation.

\section{Materials and Methods}

The experiment comprising of two irrigation methods, i.e., drip irrigation $\left(\mathrm{I}_{1}\right)$ and furrow irrigation $\left(\mathrm{I}_{2}\right)$ and five levels of nitrogen, i.e., $60 \%$ of $\mathrm{RDN}\left(\mathrm{N}_{1}\right), 80 \%$ of RDN $\left(\mathrm{N}_{2}\right), 100 \%$ of RDN $\left(\mathrm{N}_{3}\right), 120 \%$ of RDN $\left(\mathrm{N}_{4}\right)$ and $140 \%$ of RDN $\left(\mathrm{N}_{5}\right)$ was carried out at Vegetable Research Farm CCSHAU, Hisar during Rabi seasons 2015-16 and 2016-17. The date of planting was 30-10-2015 in 2015-16 and 0511-2016 in 2016-17 experiment. The treatments were laid out in split plot design with three replications. The net plot size was $3.60 \times 3.60 \mathrm{~m}$. Soil fertility status of the experimental field before experiment was shown in Table 1 . The air temperature $\left({ }^{\circ} \mathrm{C}\right)$, relative humidity (\%) and the sum of precipitation $(\mathrm{mm})$ during the potato vegetation period at the experimental field are summarized in Figure 1. Farm yard manure (FYM) @ 50 t/ha was applied prior to field preparation and full dose of phosphorus and potash were applied as basal dose. Potato tubers of $c v$. KufriBahar were planted at $60 \times 20 \mathrm{~cm}$ spacing in the last week of October. A common irrigation was applied immediately after planting in all the treatments through conventional furrow method for uniform and rapid germination. The differential drip fertigation treatments were started 20 days after planting and different doses of nitrogen was applied in seven split doses through fertigation in drip irrigation and broadcast in furrow irrigation method. The nutrient use efficiency $(\mathrm{kg} / \mathrm{ha} / \mathrm{kg})$, water use efficiency $(\mathrm{kg} / \mathrm{ha} / \mathrm{cm})$, dry matter content in tubers and foliage $(\%)$, and nutrient uptake by tubers and foliage $(\mathrm{kg} / \mathrm{ha})$ were recorded.

\section{Results and Discussion}

\section{Nutrients use efficiency $(\mathrm{kg} / \mathrm{ha} / \mathrm{kg})$}

The nitrogen levels and irrigation treatments differed significantly with respect to nutrients use efficiency during both the years 2015-16 and 2016-17 (Table 1). The maximum value of mean nutrients use efficiency (63.30 and $69.24 \mathrm{~kg} / \mathrm{ha} / \mathrm{kg}$ ) was observed with $\mathrm{N}_{3}$, which was at par with $\mathrm{N}_{4}(62.99$ and $68.42 \mathrm{~kg} / \mathrm{ha} / \mathrm{kg})$ during 2015-16 and 2016-17, respectively. It was found that drip irrigation had the maximum (61.31 and $64.78 \mathrm{~kg} / \mathrm{ha} / \mathrm{kg})$ nutrients use efficiency during both the years.

The interaction effect of irrigation methods at the same level of RDN and of RDN at the same irrigation method was found significant 
for nutrients use efficiency. In drip irrigation method, the nutrients use efficiency increased with increased levels of nitrogen up to $100 \%$ of RDN than it decreased, whereas, in furrow irrigation method, the nutrients use efficiency increased with increased levels of nitrogen during both the years. During 2015-16 and 2016-17, $100 \%$ of RDN with drip irrigation had the significantly maximum nutrients use efficiency 70.35 and $75.24 \mathrm{~kg} / \mathrm{ha} / \mathrm{kg}$, respectively.

The present findings are in harmony with the results of Badr et al., (2011) who reported that $\mathrm{N}$ rate and fertigation frequency caused significant differences in nitrogen use efficiency. It was significantly higher at low nitrogen rate as compared to higher $\mathrm{N}$ rates. The NUE was 151 and $142 \mathrm{~kg}$ yield/kg N applied @ 200 and 300 kg/ha, respectively. Similarly, Sivanappan (1980) found nitrogen use efficiency as high as $90 \%$ as compared to $40-60 \%$ in conventional method and the amount of fertilizer lost through leaching was as low as $10 \%$ in fertigation, whereas, it was $50 \%$ in the traditional system. Kumar et al., (2006) noted that the nutrients use efficiency was higher with lower rate of fertigation. The treatment $\mathrm{F}_{3}\left(\mathrm{~N}\right.$ 93: $\left.\mathrm{P}_{2} \mathrm{O}_{5} 32: \mathrm{K}_{2} \mathrm{O} 63 \mathrm{~kg} / \mathrm{ha}\right)$ recorded higher nutrients use efficiency followed by $F_{2}(141: 47: 93 \mathrm{~kg} / \mathrm{ha})$ and $\mathrm{F}_{1}$ (fertigation levels $\mathrm{N}$ 187: $\mathrm{P}_{2} \mathrm{O}_{5} \quad 63: \mathrm{K}_{2} \mathrm{O} 125$ $\mathrm{kg} / \mathrm{ha}$ ).

\section{Water use efficiency $(\mathrm{kg} / \mathrm{ha} / \mathrm{cm})$}

The water use efficiency was significantly effect by the nitrogen levels and irrigation methods (Table 1). It increased significantly with increased nitrogen levels up to $100 \%$ RDN. The highest mean value of water use efficiency was found in $\mathrm{N}_{3}$ (9.43 and 10.59 $\mathrm{kg} / \mathrm{ha} / \mathrm{cm}$ ), which was closely at par with $\mathrm{N}_{4}$ (8.31 and $9.71 \mathrm{~kg} / \mathrm{ha} / \mathrm{cm})$ and $\mathrm{N}_{2}$ (8.41 and $9.28 \mathrm{~kg} / \mathrm{ha} / \mathrm{cm}$ ) during 2015-16 and 2016-17, respectively. Drip irrigation showed significantly higher $(8.91$ and $9.47 \mathrm{~kg} / \mathrm{ha} / \mathrm{kg}$ ) water use efficiency than furrow irrigation method (7.25 and $8.69 \mathrm{~kg} / \mathrm{ha} / \mathrm{kg})$ during 2015 16 and 2016-17, respectively.

The interaction effect of irrigation method at same level of RDN and of RDN at same irrigation method was found significant for water use efficiency. Drip irrigation had maximum water use efficiency (11.66 and $12.23 \mathrm{~kg} / \mathrm{ha} / \mathrm{cm}$ ), with $\mathrm{N}_{3}$, which was at par with $\mathrm{N}_{2}$ (10.36 and $\left.10.91 \mathrm{~kg} / \mathrm{ha} / \mathrm{cm}\right)$ under same irrigation method, during 2015-16 and 2016-17, respectively.

The present findings are in harmony with the results of Lamm and Trooien (2003) reported that using drip irrigation was the best system for increasing yield, maximizing water and nitrogen use efficiency and thereby minimizing nitrate leaching. These results are in conformity with those reported earlier by Keshavaiah and Kumaraswami (1993), Patel and Patel (2001) and Sood and Singh (2003) who reported that under drip irrigation, the water use efficiency increased as compared the conventional irrigation method.

\section{Dry matter content (\%) in tuber and foliage}

The perusal of data presented in Table 2 revealed significant difference among various nitrogen levels with respect to dry matter of tuber. Among nitrogen levels, $\mathrm{N}_{3}$ (37.29 and $38.03 \%$ ) had maximum mean dry matter content in tubers during 2015-16 and 2016-17, respectively. The interaction effect of irrigation method at same level of RDN and of RDN at same irrigation method was found non-significant for dry matter content in tubers.

In potato, nitrogen levels and irrigation methods played a significant role with dry matter content in foliage. The maximum mean dry matter content in foliage was recorded 
with $\mathrm{N}_{3}$ (17.37 and 19.66\%), during 2015-16 and 2016-17.The foliage had higher dry matter content (16.88 and 18.09\%) under drip irrigation method than the foliage under furrow irrigation method, during 2015-16 and 2016-17.The interaction effect of irrigation method at same level of RDN and of RDN at same irrigation method was found nonsignificant for dry matter content in foliage. Ahmad et al., (2009) recorded increase in nitrogen fertilizer rates significantly increase tuber dry matter, specific gravity, total tuber yield, biological yield and marketable yield.

\section{Nitrogen uptake by tuber (kg/ha)}

The data pertaining to nitrogen uptake by tuber have been presented in Table 3 and showed significant difference among nitrogen levels and irrigation methods with respect to the maximum mean value for nitrogen uptake by tubers was recorded with $\mathrm{N}_{3}$ (132.61 and $133.42 \mathrm{~kg} / \mathrm{ha}$ ), which was at par with $\mathrm{N}_{4}$ (131.34 and $132.34 \mathrm{~kg} / \mathrm{ha}$ ) during 2015-16 and 2016-17, respectively. There was significant difference between mean values of nitrogen uptake by tubers with irrigation methods and the tubers higher nitrogen uptake (129.93 and $131.98 \mathrm{~kg} / \mathrm{ha}$ ) with drip irrigation showed than the tubers under furrow irrigation method
(121.32 and $123.45 \mathrm{~kg} / \mathrm{ha}$ ) during 2015-16and 2016-17, respectively. The interaction effect of irrigation method at same level of RDN and of RDN at same irrigation method was found significant for nitrogen uptake by tubers. The maximum nitrogen uptake by tuber (144.78 and $143.36 \mathrm{~kg} / \mathrm{ha}$ ) was recorded $\mathrm{inN}_{3}$ with drip irrigation during 2015-16and 2016-17, respectively. In general, the nitrogen uptake under drip irrigation with different levels of nitrogen had higher than the furrow irrigation except that $140 \%$ of RDN during both the years. Under furrow method of irrigation, the nitrogen uptake by tubers increased with increases levels of nitrogen, however, in drip irrigation, it increased up to $100 \% \mathrm{RDN}$ and decreased during 2015-16 and 2016-17.

Similar to these findings, Badr et al., (2011) reported that both nitrogen rate and fertigation frequency at shorter durations (daily, alternate and weekly) intended to stimulate the pattern of potato $\mathrm{N}$ uptake more than longest duration. The total nitrogen uptake was significantly higher with daily fertigation (180 kg N/ha) than with weekly (165 kg N/ha) and biweekly fertigation (139 kg N/ha). The lowest $\mathrm{N}$ uptake in the longest duration was most likely due to the lack of $\mathrm{NO}_{3}-\mathrm{N}$ in the root zone when the plant demand was high.

Figure.1 The air temperature $\left({ }^{\circ} \mathrm{C}\right)$, relative humidity $(\%)$ and sum of precipitation $(\mathrm{mm})$ during the potato vegetation period at the experimental field

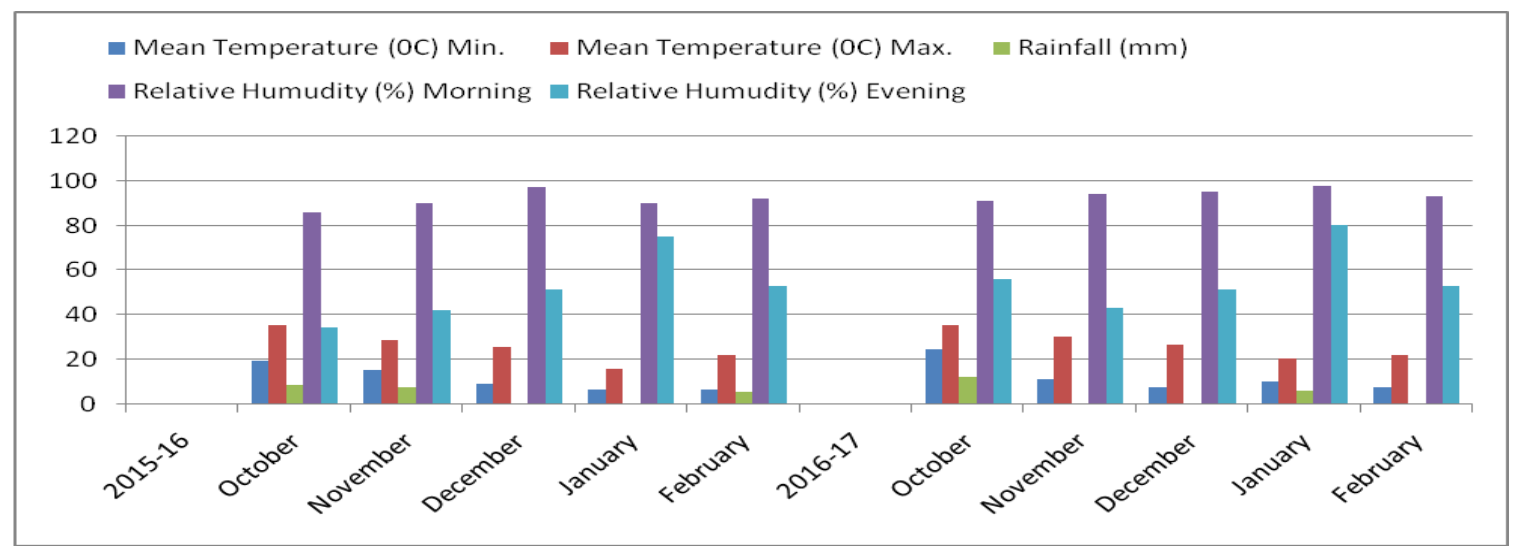


Table.1 Effect of different nitrogen levels and irrigation methods on nutrient use efficiency $(\mathrm{kg} / \mathrm{ha} / \mathrm{kg})$ and Water use efficiency $(\mathrm{kg} / \mathrm{ha} / \mathrm{cm})$ in potato crop

\begin{tabular}{|c|c|c|c|c|c|c|c|c|c|c|c|c|}
\hline \multirow{3}{*}{$\begin{array}{l}\text { Nitrogen } \\
\text { levels }\end{array}$} & \multicolumn{6}{|c|}{ Nutrient use efficiency (kg/ha/kg) } & \multicolumn{6}{|c|}{ Water use efficiency $(\mathrm{kg} / \mathrm{ha} / \mathrm{cm})$} \\
\hline & \multicolumn{3}{|c|}{ 2015-16 } & \multicolumn{3}{|c|}{ 2016-17 } & \multicolumn{3}{|c|}{$2015-16$} & \multicolumn{3}{|c|}{ 2016-17 } \\
\hline & $\begin{array}{c}\text { Drip } \\
\text { irrigation } \\
\left(\mathbf{I}_{1}\right)\end{array}$ & \begin{tabular}{|c|} 
Furrow \\
irrigation \\
$\left(\mathbf{I}_{2}\right)$
\end{tabular} & Mean & $\begin{array}{c}\text { Drip } \\
\text { irrigation } \\
\left(\mathbf{I}_{1}\right)\end{array}$ & $\begin{array}{c}\text { Furrow } \\
\text { irrigation } \\
\left(\mathbf{I}_{2}\right)\end{array}$ & Mean & $\begin{array}{c}\text { Drip } \\
\text { irrigation } \\
\left(\mathbf{I}_{1}\right)\end{array}$ & $\begin{array}{c}\text { Furrow } \\
\text { irrigation } \\
\left(\mathbf{I}_{2}\right)\end{array}$ & Mean & $\begin{array}{c}\text { Drip } \\
\text { irrigation } \\
\left(\mathbf{I}_{1}\right)\end{array}$ & $\begin{array}{c}\text { Furrow } \\
\text { irrigation } \\
\left(\mathbf{I}_{2}\right)\end{array}$ & Mean \\
\hline $\mathbf{N}_{1}$ & 52.46 & 46.57 & 49.51 & 56.57 & 50.19 & 53.38 & 6.56 & 6.11 & 6.33 & 6.82 & 6.57 & 6.70 \\
\hline $\mathbf{N}_{2}$ & 63.88 & 54.01 & 58.95 & 64.91 & 59.24 & 62.07 & 10.36 & 6.46 & 8.41 & 10.91 & 7.64 & 9.28 \\
\hline $\mathbf{N}_{3}$ & 70.35 & 56.25 & 63.30 & 75.24 & 63.24 & 69.24 & 11.66 & 7.20 & 9.43 & 12.23 & 8.94 & 10.59 \\
\hline $\mathbf{N}_{4}$ & 64.41 & 61.57 & 62.99 & 69.92 & 66.91 & 68.42 & 8.70 & 7.92 & 8.31 & 10.17 & 9.24 & 9.71 \\
\hline $\mathbf{N}_{5}$ & 55.46 & 66.22 & 60.84 & 59.24 & 68.90 & 64.07 & 7.24 & 8.58 & 7.91 & 7.46 & 10.78 & 9.12 \\
\hline Mean & 61.31 & 56.92 & & 64.78 & 61.69 & & 8.91 & 7.25 & & 9.47 & 8.69 & \\
\hline $\begin{array}{l}\text { CD at } \\
5 \% \text { level }\end{array}$ & \multicolumn{3}{|c|}{$\begin{array}{l}\mathrm{N}: 2.22 \\
\mathrm{I}: 3.70\end{array}$} & \multicolumn{3}{|c|}{$\begin{array}{l}\mathrm{N}: 1.53 \\
\mathrm{I}: 2.68\end{array}$} & \multicolumn{2}{|c|}{$\begin{array}{l}\text { I at same level of } \mathrm{N}: 1.89 \\
\mathrm{~N} \text { at same level of } \mathrm{I}: 2.00\end{array}$} & $\begin{array}{l}1.89 \\
2.00\end{array}$ & \multicolumn{2}{|c|}{$\begin{array}{l}\text { I at same level of } \mathrm{N}: 2.16 \\
\mathrm{~N} \text { at same level of } \mathrm{I}: 2.41\end{array}$} & $\begin{array}{l}2.16 \\
2.41\end{array}$ \\
\hline
\end{tabular}

$\mathrm{N}$ - Nitrogen levels, I-irrigation methods, $\mathrm{RDN}$ - recommended dose of nitrogen, $\mathrm{CD}$ - critical difference 
Table.2 Effect of different nitrogen levels and irrigation methods on dry matter (\%) in potato crop foliage and tuber in potato crop

\begin{tabular}{|c|c|c|c|c|c|c|c|c|c|c|c|c|}
\hline \multirow{3}{*}{$\begin{array}{l}\text { Nitrogen } \\
\text { levels }\end{array}$} & \multicolumn{6}{|c|}{ Foliage dry matter $(\%)$} & \multicolumn{6}{|c|}{ Tuber dry matter (\%) } \\
\hline & \multicolumn{3}{|c|}{ 2015-16 } & \multicolumn{3}{|c|}{ 2016-17 } & \multicolumn{3}{|c|}{ 2015-16 } & \multicolumn{3}{|c|}{ 2016-17 } \\
\hline & $\begin{array}{c}\text { Drip } \\
\text { irrigation } \\
\left(\mathbf{I}_{1}\right)\end{array}$ & $\begin{array}{c}\text { Furrow } \\
\text { irrigation } \\
\left(\mathbf{I}_{2}\right)\end{array}$ & Mean & $\begin{array}{c}\text { Drip } \\
\text { irrigation } \\
\left(\mathbf{I}_{1}\right)\end{array}$ & $\begin{array}{c}\text { Furrow } \\
\text { irrigation } \\
\left(\mathbf{I}_{2}\right)\end{array}$ & Mean & $\begin{array}{c}\text { Drip } \\
\text { irrigation } \\
\left(\mathbf{I}_{1}\right)\end{array}$ & $\begin{array}{c}\text { Furrow } \\
\text { irrigation } \\
\left(\mathbf{I}_{2}\right)\end{array}$ & Mean & $\begin{array}{c}\text { Drip } \\
\text { irrigation } \\
\left(\mathbf{I}_{1}\right)\end{array}$ & $\begin{array}{c}\text { Furrow } \\
\text { irrigation } \\
\left(\mathbf{I}_{2}\right)\end{array}$ & Mean \\
\hline $\mathbf{N}_{1}$ & 12.95 & 9.56 & 11.26 & 12.98 & 11.43 & 12.21 & 35.02 & 25.21 & 30.12 & 30.21 & 23.14 & 26.68 \\
\hline $\mathbf{N}_{2}$ & 18.98 & 11.98 & 15.48 & 20.89 & 14.90 & 17.90 & 40.45 & 29.96 & 35.21 & 41.50 & 29.17 & 35.34 \\
\hline $\mathbf{N}_{3}$ & 20.76 & 13.98 & 17.37 & 22.87 & 16.45 & 19.66 & 41.60 & 32.98 & 37.29 & 41.83 & 34.23 & 38.03 \\
\hline $\mathbf{N}_{4}$ & 16.96 & 15.98 & 16.47 & 18.64 & 18.64 & 18.64 & 39.65 & 34.85 & 37.25 & 37.83 & 36.58 & 37.21 \\
\hline $\mathbf{N}_{5}$ & 14.76 & 17.56 & 16.16 & 15.09 & 20.87 & 17.98 & 37.40 & 36.92 & 37.16 & 33.77 & 37.47 & 35.62 \\
\hline Mean & 16.88 & 13.81 & & 18.09 & 16.46 & & 38.82 & 31.98 & & 37.03 & 32.12 & \\
\hline $\begin{array}{l}\text { CD at } \\
5 \% \text { level }\end{array}$ & \multicolumn{3}{|c|}{$\begin{array}{l}\mathrm{N}: 0.93 \\
\mathrm{I}: 0.87\end{array}$} & $\begin{array}{l}\text { I at sam } \\
\mathrm{N} \text { at sar }\end{array}$ & $\begin{array}{l}\mathrm{N}: 1.20 \\
\mathrm{I}: 0.95 \\
\text { level of } \mathrm{N} \\
\text { ne level of }\end{array}$ & $\begin{array}{l}\text { : NS } \\
: \text { NS }\end{array}$ & $\begin{array}{l}\mathrm{I} \text { at sam } \\
\mathrm{N} \text { at sar }\end{array}$ & $\begin{array}{l}\mathrm{N}: 5.24 \\
\mathrm{I}: \mathrm{NS} \\
\text { e level of } \mathrm{N} \\
\text { ne level of }\end{array}$ & $\begin{array}{l}\text { : NS } \\
: N S\end{array}$ & $\begin{array}{l}\text { I at sam } \\
\mathrm{N} \text { at sar }\end{array}$ & $\begin{array}{l}\text { N: } 2.86 \\
\text { I : NS } \\
\text { e level of } N \\
\text { ne level of I }\end{array}$ & $\begin{array}{l}\text { NS } \\
\text { NS }\end{array}$ \\
\hline
\end{tabular}

$\mathrm{N}$ - Nitrogen levels, I-irrigation methods, RDN - recommended dose of nitrogen, $\mathrm{CD}$ - critical difference 
Int.J.Curr.Microbiol.App.Sci (2018) 7(11): 1969-1976

Table.3 Effect of different nitrogen levels and irrigation method on nitrogen uptake by tuber and foliage (kg/ha) in potato crop

\begin{tabular}{|c|c|c|c|c|c|c|c|c|c|c|c|c|}
\hline \multirow{3}{*}{$\begin{array}{l}\text { Nitrogen } \\
\text { levels }\end{array}$} & \multicolumn{6}{|c|}{ Nitrogen uptake by tuber (kg/ha) } & \multicolumn{6}{|c|}{ Nitrogen uptake by foliage (kg/ha) } \\
\hline & \multicolumn{3}{|c|}{$2015-16$} & \multicolumn{3}{|c|}{ 2016-17 } & \multicolumn{3}{|c|}{$2015-16$} & \multicolumn{3}{|c|}{ 2016-17 } \\
\hline & $\begin{array}{c}\text { Drip } \\
\text { irrigation } \\
\left(I_{1}\right)\end{array}$ & $\begin{array}{c}\text { Furrow } \\
\text { irrigation } \\
\left(\mathbf{I}_{2}\right)\end{array}$ & Mean & $\begin{array}{c}\text { Drip } \\
\text { irrigation } \\
\left(\mathbf{I}_{1}\right)\end{array}$ & $\begin{array}{c}\text { Furrow } \\
\text { irrigation } \\
\left(\mathbf{I}_{2}\right)\end{array}$ & Mean & $\begin{array}{c}\text { Drip } \\
\text { irrigation } \\
\left(\mathbf{I}_{1}\right)\end{array}$ & $\begin{array}{c}\text { Furrow } \\
\text { irrigation } \\
\left(\mathbf{I}_{2}\right)\end{array}$ & Mean & $\begin{array}{c}\text { Drip } \\
\text { irrigation } \\
\left(\mathbf{I}_{1}\right)\end{array}$ & $\begin{array}{c}\text { Furrow } \\
\text { irrigation } \\
\left(\mathbf{I}_{2}\right)\end{array}$ & Mean \\
\hline $\mathbf{N}_{1}$ & 118.05 & 110.76 & 114.40 & 120.36 & 113.42 & 116.89 & 3.51 & 1.70 & 2.61 & 3.51 & 2.61 & 3.06 \\
\hline $\mathbf{N}_{2}$ & 131.61 & 117.98 & 124.80 & 135.06 & 119.69 & 127.38 & 4.55 & 2.64 & 3.60 & 4.55 & 3.60 & 4.07 \\
\hline $\mathbf{N}_{3}$ & 144.78 & 120.44 & 132.61 & 143.36 & 123.47 & 133.42 & 5.62 & 2.75 & 4.18 & 5.62 & 4.18 & 4.90 \\
\hline $\mathbf{N}_{4}$ & 136.97 & 125.70 & 131.34 & 137.66 & 127.03 & 132.34 & 4.49 & 3.17 & 3.83 & 4.49 & 3.83 & 4.16 \\
\hline $\mathbf{N}_{5}$ & 121.52 & 131.72 & 126.62 & 123.45 & 133.66 & 128.56 & 3.54 & 3.56 & 3.55 & 3.54 & 3.55 & 3.55 \\
\hline Mean & 129.93 & 121.32 & & 131.98 & 123.45 & & 4.34 & 2.76 & & 4.34 & 3.55 & \\
\hline $\begin{array}{l}\text { CD at } \\
5 \% \text { level }\end{array}$ & \multicolumn{3}{|c|}{$\begin{array}{l}\mathrm{N}: 1.76 \\
\mathrm{I}: 2.51\end{array}$} & \multicolumn{3}{|c|}{$\begin{array}{l}\mathrm{N}: 1.37 \\
\mathrm{I}: 3.87\end{array}$} & $\begin{array}{l}\mathrm{I} \text { at same } \\
\mathrm{N} \text { at sam }\end{array}$ & $\begin{array}{l}\text { N: } 0.70 \\
\text { I : } 0.29 \\
\text { level of } \mathrm{N} \\
\text { e level of I }\end{array}$ & $\begin{array}{l}0.92 \\
1.01\end{array}$ & $\begin{array}{l}\mathrm{I} \text { at sam } \\
\mathrm{N} \text { at sam }\end{array}$ & $\begin{array}{l}\text { N: } 1.17 \\
\mathrm{I}: 0.72 \\
\text { level of } \mathrm{N} \\
\text { e level of } \mathrm{I}\end{array}$ & $\begin{array}{l}1.60 \\
1.74\end{array}$ \\
\hline
\end{tabular}


Int.J.Curr.Microbiol.App.Sci (2018) 7(11): 1969-1976

Table.4 Effect of different nitrogen levels and irrigation methods on phosphorous uptake by tuber and foliage in potato crop

\begin{tabular}{|c|c|c|c|c|c|c|c|c|c|c|c|c|}
\hline \multirow{3}{*}{$\begin{array}{l}\text { Nitrogen } \\
\text { levels }\end{array}$} & \multicolumn{6}{|c|}{ Phosphorous uptake by tubers (kg/ha) } & \multicolumn{6}{|c|}{ Phosphorous uptake by foliage (kg/ha) } \\
\hline & \multicolumn{3}{|c|}{ 2015-16 } & \multicolumn{3}{|c|}{ 2016-17 } & \multicolumn{3}{|c|}{ 2015-16 } & \multicolumn{3}{|c|}{$2016-17$} \\
\hline & $\begin{array}{c}\text { Drip } \\
\text { irrigation } \\
\left(\mathbf{I}_{1}\right)\end{array}$ & $\begin{array}{c}\text { Furrow } \\
\text { irrigation } \\
\left(\mathbf{I}_{2}\right)\end{array}$ & Mean & $\begin{array}{c}\text { Drip } \\
\text { irrigation } \\
\left(\mathbf{I}_{1}\right)\end{array}$ & $\begin{array}{c}\text { Furrow } \\
\text { irrigation } \\
\left(\mathbf{I}_{2}\right)\end{array}$ & Mean & $\begin{array}{c}\text { Drip } \\
\text { irrigation } \\
\left(\mathbf{I}_{1}\right)\end{array}$ & $\begin{array}{c}\text { Furrow } \\
\text { irrigation } \\
\left(\mathbf{I}_{2}\right)\end{array}$ & Mean & $\begin{array}{c}\text { Drip } \\
\text { irrigation } \\
\left(\mathbf{I}_{1}\right)\end{array}$ & $\begin{array}{c}\text { Furrow } \\
\text { irrigation } \\
\left(\mathbf{I}_{2}\right)\end{array}$ & Mean \\
\hline $\mathbf{N}_{1}$ & 170.60 & 156.69 & 163.65 & 167.25 & 151.36 & 159.31 & 8.20 & 6.97 & 7.59 & 9.57 & 7.49 & 8.53 \\
\hline $\mathbf{N}_{2}$ & 197.33 & 174.39 & 185.86 & 192.28 & 169.25 & 180.77 & 13.25 & 10.30 & 11.77 & 14.41 & 11.43 & 12.92 \\
\hline $\mathbf{N}_{3}$ & 206.41 & 180.32 & 193.36 & 205.25 & 176.25 & 190.25 & 18.27 & 11.36 & 14.89 & 16.90 & 12.44 & 14.67 \\
\hline $\mathbf{N}_{4}$ & 199.36 & 186.66 & 193.01 & 194.36 & 183.36 & 188.86 & 15.17 & 12.61 & 13.89 & 15.45 & 12.65 & 14.05 \\
\hline $\mathbf{N}_{5}$ & 177.65 & 196.31 & 186.98 & 172.22 & 189.25 & 180.74 & 9.47 & 14.56 & 12.02 & 9.36 & 15.33 & 12.34 \\
\hline Mean & 189.67 & 178.87 & & 184.47 & 173.89 & & 12.47 & 11.16 & & 13.14 & 11.87 & \\
\hline $\begin{array}{l}\text { CD at } \\
5 \% \text { level }\end{array}$ & $\begin{array}{l}\mathrm{I} \text { at sam } \\
\mathrm{N} \text { at san }\end{array}$ & $\begin{array}{l}\mathrm{N}: 1.76 \\
\mathrm{I}: 2.51 \\
\text { level of } \mathrm{N} \\
\text { le level of }\end{array}$ & $\begin{array}{l}3.31 \\
: 3.11\end{array}$ & $\begin{array}{l}\mathrm{I} \text { at sam } \\
\mathrm{N} \text { at sar }\end{array}$ & $\begin{array}{l}\mathrm{N}: 1.37 \\
\mathrm{I}: 3.87 \\
\text { level of } \mathrm{N} \\
\text { e level of } 1\end{array}$ & $\begin{array}{l}: 3.99 \\
: 3.10\end{array}$ & $\begin{array}{l}\mathrm{I} \text { at sam } \\
\mathrm{N} \text { at san }\end{array}$ & $\begin{array}{l}\mathrm{N}: .70 \\
\mathrm{I}: .03 \\
\text { level of } \mathrm{N} \\
\text { level of } \mathrm{I}\end{array}$ & $\begin{array}{l}0.92 \\
1.02\end{array}$ & $\begin{array}{l}\text { I at sam } \\
\mathrm{N} \text { at sal }\end{array}$ & $\begin{array}{l}\mathrm{N}: 1.06 \\
\mathrm{I}: 0.39 \\
\text { level of } \mathrm{N} \\
\text { le level of }\end{array}$ & $\begin{array}{l}2.36 \\
2.12\end{array}$ \\
\hline
\end{tabular}




\section{Nitrogen uptake by foliage $(\mathrm{kg} / \mathrm{ha})$}

The data presented in Table 3 show that there was significant differences among the various levels of irrigation methods with respect to nutrient uptake by foliage in both the years. The nutrient uptake by foliage increased significantly with the increase in the level of nitrogen up to $100 \%$ RDN and then decreased. The uppermost value of nutrient uptake by foliage $(4.18$ and $4.90 \mathrm{~kg} / \mathrm{ha})$ was recorded with $\mathrm{N}_{3}$, which was at par with $\mathrm{N}_{4}$ (3.83 and $4.16 \mathrm{~kg} / \mathrm{ha}$ ) and $\mathrm{N}_{2}$ (3.60 and 4.07 $\mathrm{kg} / \mathrm{ha}$ ) during 2015-16 and 2016-17, respectively. In case of irrigation methods, the drip irrigation method had maximum nitrogen uptake by tubers than furrow irrigation method during both the years.

\section{Phosphorous uptake by tubers (kg/ha)}

It was observed that the difference in phosphorous uptake by tubers was significant under nitrogen levels during both the years (Table 4). The phosphorous uptake by tubers increased significantly with increased nitrogen levels up to $100 \% \mathrm{RDN}$ and then decreased. The uppermost mean value of phosphorous uptake by tubers (193.36 and $190.25 \mathrm{~kg} / \mathrm{ha}$ ) was recorded with $100 \%$ of RDN, which was at par with $120 \%$ of RDN (193.01kg/ha), during 2015-16 and 2016-17, respectively. There was also significantly difference among the irrigation methods during both the years and the drip irrigation had the higher mean value of phosphorous uptake by tubers $(189.67$ and $184.47 \mathrm{~kg} / \mathrm{ha})$ than the furrow method of irrigation (178.87 and $173.89 \mathrm{~kg} / \mathrm{ha}$ ) during both the years. The interaction effect of irrigation method at same level of RDN and of RDN at the same irrigation method was found significant for phosphorous uptake by tubers. The significantly maximum phosphorous uptake by tubers $(206.41$ and $205.25 \mathrm{~kg} / \mathrm{ha}$ ) was found in $100 \%$ of RDN with drip irrigation, during 2015-16 and 2016-17, respectively.

\section{Phosphorous uptake by foliage (kg/ha)}

The nutrient uptake by foliage increased significantly with increased nitrogen level up to $100 \%$ RDN and then decreased significantly. The uppermost value of phosphorous uptake by foliage (14.89 and $14.67 \mathrm{~kg} / \mathrm{ha}$ ) was recorded with $100 \%$ of RDN, during 2015-16 and 2016-17, respectively.

Drip irrigation showed significantly higher values of phosphorous uptake (12.47 and $13.14 \mathrm{~kg} / \mathrm{ha}$ ) during both the years, respectively. The interaction effect of irrigation method at same level of RDN and of RDN at same irrigation method was found significant for phosphorous uptake by foliage. The significantly maximum phosphorous uptake by foliage (18.27 and $16.90 \mathrm{~kg} / \mathrm{ha})$ was found in $100 \%$ of RDN with drip irrigation, during2015-16 and 2016-17, respectively.

Based on the present experimental results, it is concluded that the irrigation method and nitrogen levels improved the growth and yield of potato crop. Drip irrigation with $100 \%$ of RDN (150 kg/ha) was found superior to nutrients and water use efficiencyof potato, which was comparatively higher than the yield of potato under furrow irrigation method. The maximum nutrients (nitrogen and phosphorus) uptake and dry matter content was measured with drip irrigation in tubers and foliage.

\section{References}

Ahmad, A., Mohamad, E, Gohaname, A. and Riad, G. (2009). Potato Tuber Quality as Affected by Nitrogen Form and Rate. Middle Eastern and Russian Journal of Plant Sciences and Biotechnology. Global Science Book.

Anonymous, 2016. Potato all India Production.www.nhm.nic.in/Archi ve/ICAR-5.PDF 
Badr, M.A., Taalab, A.S. and El-Tohamy, W.A. (2011). Nitrogen application rate and fertigation frequency for dripirrigated potato (Solanum tuberosum). Australian Journal of Basic and Applied Sciences, 5(7): 817-825.

Keshavaiah, K.V. and Kumaraswami, A.S. (1993). Fertigation and water use efficiency in potato under furrow and drip irrigation. Journal of Indian Potato Association, 20: 240-244.

Kumar, M., Trehan, S.P and Singh, S.N. (2006). Growth period specific nitrogen requirement of potato in the Indo-Gangetic plains of Bihar. Potato Journal, 33(3-4): 166-167.

Kumar, S., Mandal, G., Asrey, R. and Singh, R. (2006). Influence of irrigation and fertigation on yield, production efficiency and economic returns of drip irrigated potato under semi-arid environment. Potato Journal, 33(3-4): 126-130.

Lamm, F.R. and Trooien, T.P. (2003). Subsurface drip irrigation for corn productivity: A review of 10 years of research in Kansas. Irrigation Science, 22(3-4): 195-200.

Nath, P., Srivastva, V.K., Dutta, O.P. and
Swamy, K.R.M. (2008). Vegetable Crops: Improvement and Production. Jwalamukhi Job Press, Karnataka, India, $398 \mathrm{p}$.

Pandey, S. K. (2007). Vegetable Science. Central Potato Research Institute, Shimla, H.P.

Pandey, S.K. and Sarkar, D. (2005). Potato in India: emerging trends and challenges in the new millennium. Potato Journal, 32(3-4): 93-104.

Patel, J.C. and Patel, B.K. (2001). Response of potato to nitrogen under drip and furrow methods of irrigation. Journal of Indian Potato Association, 28: 29395.

Sivanappan, R.K. and Padmakumari, O. (1980). Sustainable micro-irrigation management for trees and vines. Research advances in sustainable micro-irrigation, Tamil Nadu Agricultural University, Coimbatore, 3: 79-94.

Sood, M.C. and Singh, N. (2003). Effect of N fertigation and planting methods on potato growth and yield in Shimla hills. Journal of Indian Potato Association, 30: 65-66.

\section{How to cite this article:}

Devashri Maan, A.K. Bhatia, Vikram and Anshul Duhan. 2018. Response of Nitrogen Rates and Irrigation Methods on Nutrients Uptake, Nitrogen and Water Use Efficiency on Potato. Int.J.Curr.Microbiol.App.Sci. 7(11): 1969-1976. doi: https://doi.org/10.20546/ijcmas.2018.711.223 